\title{
Flood Moderation \& Water Management Study in a Non-Himalayan Indian Basin
}

\author{
Sanjay Kumar Ray*, Venkappayya Rangappayya Desai \\ Civil Engineering Department, Indian Institute of Technology Kharagpur, West Bengal, India \\ Email address: \\ sanjayiitg632@iitkgp.ac.in (S. K. Ray), venkapd@civil.iitkgp.ac.in (V. R. Desai) \\ ${ }^{*}$ Corresponding author
}

To cite this article:

Sanjay Kumar Ray, Venkappayya Rangappayya Desai. Flood Moderation \& Water Management Study in a Non-Himalayan Indian Basin. American Journal of Water Science and Engineering. Vol. 6, No. 3, 2020, pp. 89-103. doi: 10.11648/j.ajwse.20200603.12

Received: September 17, 2020; Accepted: September 30, 2020; Published: October 13, 2020

\begin{abstract}
India is one of the very few countries in the world endowed with substantial land and water resources. Being a country with predominantly monsoon climate, the rainfall is erratic, unevenly distributed in space, time and hence droughts in some parts/seasons and floods in some other parts/seasons frequently occur. Sometimes, both of them also occur simultaneously. In order to reduce the adverse impacts of floods and droughts, intra-basin surface/subsurface water management followed by inter-basin subsurface \& surface water transfer is proposed to ensure water availability within the basin first, followed by transfer of basin excess water, preferably to the adjacent basin (s) within the region -having water storage capability during the regional floods, purely on a short term basis. In the present study, a sub-catchment of Subarnarekha Basin has been considered as the study area. This study focuses on the proposal of Intra-basin/Inter-basin subsurface/surface storage/transfer during a portion of the flood period. This is accomplished after creating some Intra-basin storage, by analyzing 13 years of daily discharge data -starting from 2004, for the Jamsholaghat Gauge-Discharge (G-D) site in the basin. Thus, all the four purposes -in their order of preference, viz., 1) moderation of basin flood peak; 2) creation of intrabasin surface/subsurface storage; 3) groundwater recharge and 4) short term mitigation of water scarcity in the neighboring basin (s), are expected to be achieved through this proposal.
\end{abstract}

Keywords: Interlinking of Rivers, Inter-basin Transfer, Subsurface Transfer, Water Harvesting Structures

\section{Introduction}

On the Earth's surface, the freshwater availability generally depends on the hydrological cycle. If the technologies such as desalination of sea water are used extensively, then it would further increase the availability of freshwater [1]. Due to increase in the global population and change in the climate conditions, there will be increases in the demand of freshwater which may lead to shortage of water resources spatially and/or temporally. Hence, proper planning is needed for judicious water utilization -for striking balance between demand and supply, supply and utilization at global/regional/local scales for ensuring sustained availability of water. Here, the concept of basin water management and Inter-basin water transfer or river interlinking comes into picture. India is a large developing country and keeping its population growth in mind, India is expected to face severe water shortages in the near future. Climatic and geographic variability causing the drought conditions results in the suffering of humans/animals in different regions of India. Droughts cause water shortage mainly for domestic, agricultural and industrial purposes. The proposal for interlinking of rivers (ILR) of India is on the wish list of many stakeholders in order to reduce the negative impacts of droughts in some regions by utilizing the simultaneously prevailing excess flood waters in some other regions.

\section{Literature Review}

Literatures have been reviewed from 1990 to 2017, out of which few literature reviews have been shown in brief. Rao former irrigation minister of India showed his concern towards the shortage of water in future and he proposed the linking of river is one of the possible way to overcome from this shortage [2]. Since then many researches, proposals, plans and actions have been carried out in order to overcome 
the shortage of water for future generation [3-5].

Bhaduri and Bharbier presented a study on the inter-basin water transfer proposed for India through an Ex-ante based analysis of the water transferred between the surplus and deficit basins. Ex-ante analysis has been used, in order to get an idea of the price movement or the impact of newly adopted policies on the future [6].

Bonkile and Pajgade presented a study showing the different methods and techniques, all the possibilities of past work those are being used in order to transfer the surface water in case of inter-basin and intra-basin [7].

George et al. highlighted the concept of Inter-basin water transfer along with their resulting problems and economic/ecological benefits, which may lead to a sustainable development of that region [8].

Gupta and Zaag presented a study by considering the interbasin surface water transfer as a part of integrated water resource management. The authors considers all the criteria proposed by international commissions, scientists in order to access whether this transfer falls under the integrated water resource management or not [9].

Hamaideh et al. presented an experimental study on Wadi Ishe in Jordan to show the effect of an artificial groundwater recharge technique (viz., recharge of surface runoff and to store that water in an artificial groundwater reservoir) to reduce the loss due to evaporation and an alternative of water supply for rural areas [10].

Mahabaleshwara and Nagabhushan highlighted on interlinking of river as an agenda by considering the shortage of water due to the current trend of precipitation and the would ultimately cause shortage of surface water availability [11].

Pelkey presented an article on interlinking of river. The author has discussed in details regarding the California's state water project, its pumping cost, total lift and what are the problems associated with construction. The author also proposed the few potential canals as suggested by National Prospective Plans [12, 13].

Verdhen presented a study to show the efforts made by the Madhya Pradesh state government in India, to preserve the people's hope at present and future towards water availability by developing intra-basin schemes and interlinking of subbasins (i.e., Deb-Goi Rivers in the district of Barwani) through sustainable studies [14].

Vyas et al. presented a study on the interlining concept by considering the five river basins of Rajasthan in India. Their proposal includes connecting the lower areas of Chambal basin with the lower areas of Banas, Gambhir, Banganga and Parbati basins. The main reason behind this linking was to mitigate the flood situation in Chamal vicinity and also to mitigate the drought conditions in other four basins [15].

After reviewing the relevant literature, following gaps have been identified:

1) None of the literature reviewed so far have proposed any method for optimizing depth and cost of excavation in the link channels.

2) Surface link channels involves large land acquisition and associated problems like relief \& rehabilitation. None of the studies - except one generic study, have so far have proposed any method to overcome this problem.

3) Identifying a particular basin as either a surplus basin or deficit basin is controversial and is also influenced by climate change as well as upstream unilateral Interbasin transfers, e.g., due to the unilateral diversion of the flow from Yarlung Tsangpo (i.e., Brahmaputra River) in the Tibetian autonomous region of China, the Brahmaputra River flowing through the NE India, can no longer be identified as a surplus basin. Due to climate change induced intense storms, many of the so called deficit basins are also affected by floods occasionally. Likewise, many of the 'Surplus basins' do get affected by continual/continuous water scarcity/drought conditions due to a general reduction in the number of rainy days and a long gap between two successive rainy days. However, there is no difference of opinion as far as utilizing the short term Inter-basin transfer especially during flood period, purely for the purpose of the flood moderation.

4) There is no provision for reversing the flow direction in the interlinking surface channels. Thus, it is not possible to ensure two-way Inter-basin surface water transfer between two neighboring basins. This forms a major limiting factor.

5) Since the basin or catchment or watershed is having a natural boundary, Intra-basin storage and transfer need to be given a higher priority than inter-basin transfer. This aspect appears to have been overlooked, in all the literature reviewed here.

\section{Methodology}

This chapter deals with the methodology involved in this study. It starts from the delineation of Jamsholaghat catchment area which is a sub-catchment of the Subarnarekha basin, for which ArcGIS software has been used. This was followed by an analysis of the daily Gauge-Discharge (G-D) data from 2004 to 2016 for Jamsholaghat G-D site in order to estimate the peak discharge and to analyze the various feasible flood management (FM) techniques [16]. It also includes the steps involved in selecting the suitable water harvesting structures.

\subsection{Study Area}

Study area involves the Jamsholaghat sub-catchment of the Subarnarekha Basin. The present study area extends over parts of the Eastern Indian states of Odisha and West Bengal, having a total area of $552 \mathrm{~km}^{2}$. It lies between $86^{\circ} 30^{\prime}$ and $86^{\circ} 50^{\prime} \mathrm{E}$ longitudes as well as $22^{\circ} 04^{\prime}$ and $22^{\circ} 32^{\prime} \mathrm{N}$ latitudes. The Subarnarekha and the Burhabalang form the major river systems in the sub-catchment. Length of the Subarnarekha River and Burhabalang River is $22.74 \mathrm{~km}$ and $44.32 \mathrm{~km}$ respectively [17]. Delineated DEM of study area in Subarnarekha Basin is shown in Figure 1. 


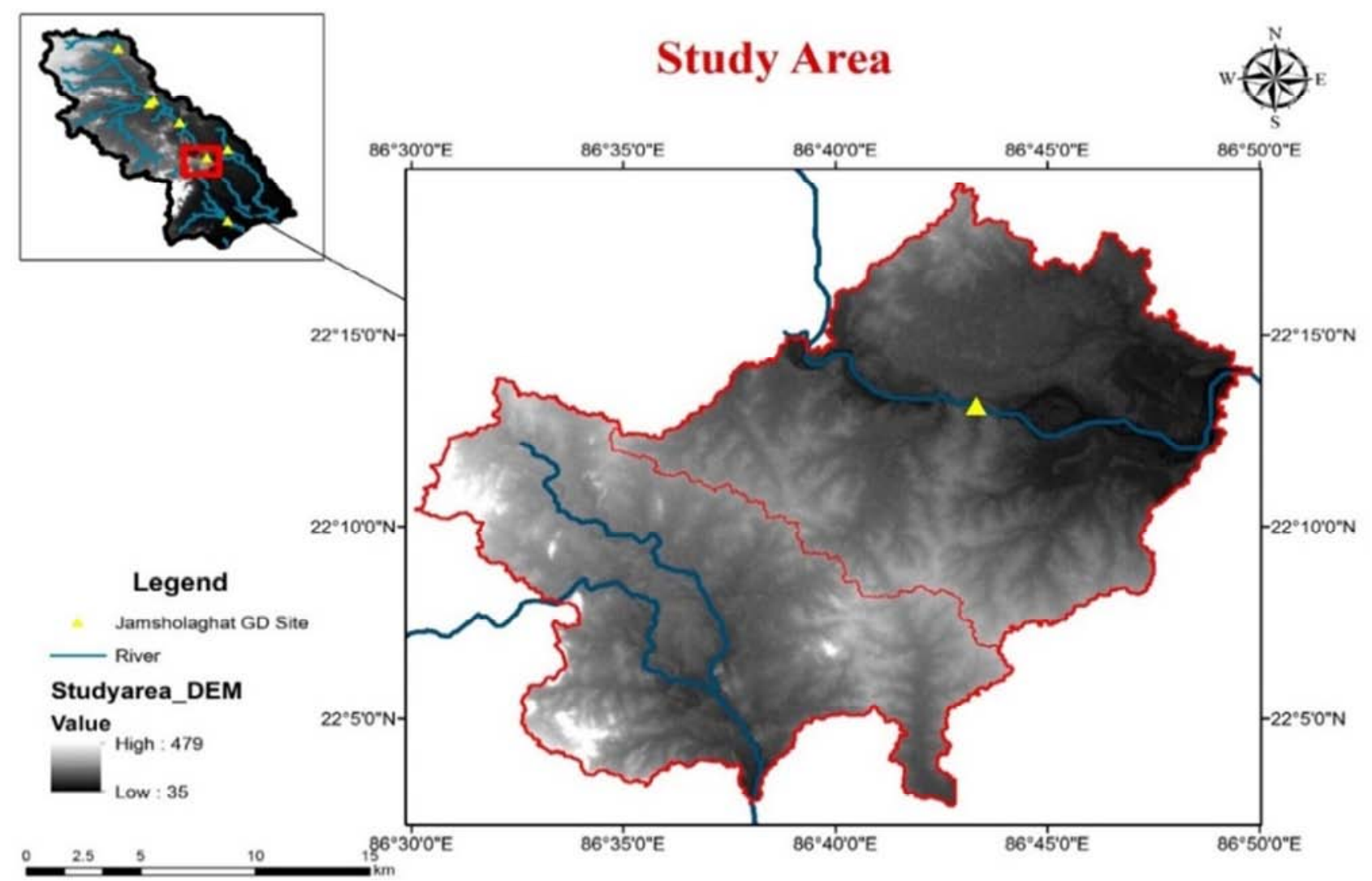

Figure 1. Delineated DEM of study area in Subarnarekha Basin.

\subsection{Flood Management (FM) Scenarios}

For the study area, four FM scenarios are considered as shown in Table 1. To ensure sustainable water management within two neighboring basins, each FM scenarios has been divided into $6 \mathrm{FM}$ techniques based on the priority level and proportioning requirement. For each scenario, discharges and volumes have been estimated.

Table 1. Flood Management (FM) Scenario.

\begin{tabular}{llllll}
\hline SI No. & Flood Management Scenario & I & II & III & IV \\
\hline 1 & Intra-basin Surface Storage & $25 \%$ & $30 \%$ & $35 \%$ & $40 \%$ \\
2 & Intra-basin Surface Transfer & $20 \%$ & $15 \%$ & $10 \%$ & $5 \%$ \\
$3 \mathrm{a}$ & Inter-basin subsurface Storage & $33 \%$ & $34 \%$ & $35 \%$ & $36 \%$ \\
$3 \mathrm{~b}$ & Inter-basin subsurface Transfer & $7 \%$ & $6 \%$ & $5 \%$ & $4 \%$ \\
$3 \mathrm{c}$ & Inter-basin surface Storage & $11 \%$ & $10 \%$ & $9 \%$ & $8 \%$ \\
$3 \mathrm{~d}$ & Inter-basin surface Transfer & $4 \%$ & $5 \%$ & $6 \%$ & $7 \%$ \\
Total & & $100 \%$ & $100 \%$ & $100 \%$ & $100 \%$ \\
\hline
\end{tabular}

\subsubsection{Intra-basin Surface Storage}

Intra-basin surface storage means making surface storage available within the basin itself. The existing facilities available are as follows: stream channels, drainage channels, surface depressions and flood plains. The volumes of these existing facilities have been estimated using a Geographic Information System (GIS) software. For estimation of volumes of stream channels, drainage channels and flood plains, approximated lengths and cross-sections of the channels have been used. For volume estimation of surface depressions, contour maps of $5 \mathrm{~m}$ interval and topo-sheets of the study area have been used.

After estimating the volumes of stream channels, drainage channels, flood plains and surface depressions, additional flood volume could be created using subsurface dykes, relief wells and check dams. In the present work, relief wells have been used to create the additional flood storage volumes.

\subsubsection{Intra-basin Surface Transfer}

Intra-basin surface transfer means transferring the surplus water within the basin itself through existing drainage channels. The facilities available are stream channels and drainage channels. The volumes of these existing facilities have been estimated using a GIS software. For estimation of stream channel and drainage channel volumes, approximated lengths and cross-sections of channels have been used.

After estimating the surface channel and drainage channel volumes, additional flood storage volume could be created using diversion channels and other canals.

\subsubsection{Inter-basin Subsurface Storage}

Inter-basin subsurface storage means making subsurface storage available within a neighboring basin. In order to estimate the subsurface storage, lithological data is required. This data has been collected from Central Ground Water Board (CGWB), Bhubaneswar, Odisha, India [18]. Lithological data gives the details of different layers of soils/rocks available below the ground surface. Such data for 8 existing wells have been collected in order to estimate the subsurface storage. Depth details of the aquifers having 3 different layers for each 
of these 8 existing wells have been given in Table 2 .

Table 2. Elevations and Depths of Aquifers.

\begin{tabular}{|c|c|c|c|c|c|c|c|c|c|}
\hline \multirow{2}{*}{$\begin{array}{l}\text { Existing } \\
\text { Well }(E W)\end{array}$} & \multicolumn{3}{|c|}{ Unconfined Aquifer } & \multicolumn{3}{|c|}{ 1st Confined Aquifer } & \multicolumn{3}{|c|}{ 2nd Confined Aquifer } \\
\hline & $\begin{array}{l}\text { Ground } \\
\text { Elevation (m) }\end{array}$ & $\begin{array}{l}\text { Bottom } \\
\text { Elevation (m) }\end{array}$ & $\begin{array}{l}\text { Depth } \\
\text { (m) }\end{array}$ & $\begin{array}{l}\text { Top Elevation } \\
\text { (m) }\end{array}$ & $\begin{array}{l}\text { Bottom } \\
\text { Elevation (m) }\end{array}$ & $\begin{array}{l}\text { Depth } \\
\text { (m) }\end{array}$ & $\begin{array}{l}\text { Top Elevation } \\
\text { (m) }\end{array}$ & $\begin{array}{l}\text { Bottom } \\
\text { Elevation (m) }\end{array}$ & $\begin{array}{l}\text { Depth } \\
\text { (m) }\end{array}$ \\
\hline $\mathrm{EW}_{1}$ & 69.0 & 17.6 & 51.4 & -21.4 & -143.4 & 122.0 & -206.5 & -227.2 & 20.7 \\
\hline $\mathrm{EW}_{2}$ & 66.0 & 21.5 & 44.5 & -24.6 & -148.6 & 124.0 & -213.3 & -229.3 & 16.0 \\
\hline $\mathrm{EW}_{3}$ & 69.3 & 19.2 & 50.1 & -21.2 & -141.3 & 120.1 & -208.6 & -227.3 & 18.7 \\
\hline $\mathrm{EW}_{4}$ & 66.2 & 16.2 & 50.0 & -24.2 & -124.2 & 100.0 & -207.5 & -229.8 & 22.3 \\
\hline $\mathrm{EW}_{5}$ & 78.0 & 48.4 & 29.6 & -12.4 & -93.1 & 80.7 & -192.6 & -216.5 & 23.9 \\
\hline $\mathrm{EW}_{7}$ & 72.0 & 52.0 & 20.0 & -18.3 & -81.0 & 62.7 & -207.1 & -223.8 & 16.7 \\
\hline $\mathrm{EW}_{8}$ & 75.6 & 54.6 & 21.0 & -15.8 & -82.8 & 67.0 & -200.1 & -219.6 & 19.5 \\
\hline
\end{tabular}

i. Steps involved in Estimating Subsurface Storage

a) Ground elevations for each of the existing wells have been obtained from Google Earth.

b) The groundwater flow direction in different aquifers within the different existing wells have been estimated by piezometric head analysis as shown by a diagram using a Computer Aided Drafting (CAD) software in Figure 2.

c) The inflow \& outflow discharges through different aquifers for the existing wells in all confined \& unconfined aquifers have been estimated using Theim's Equation [19].

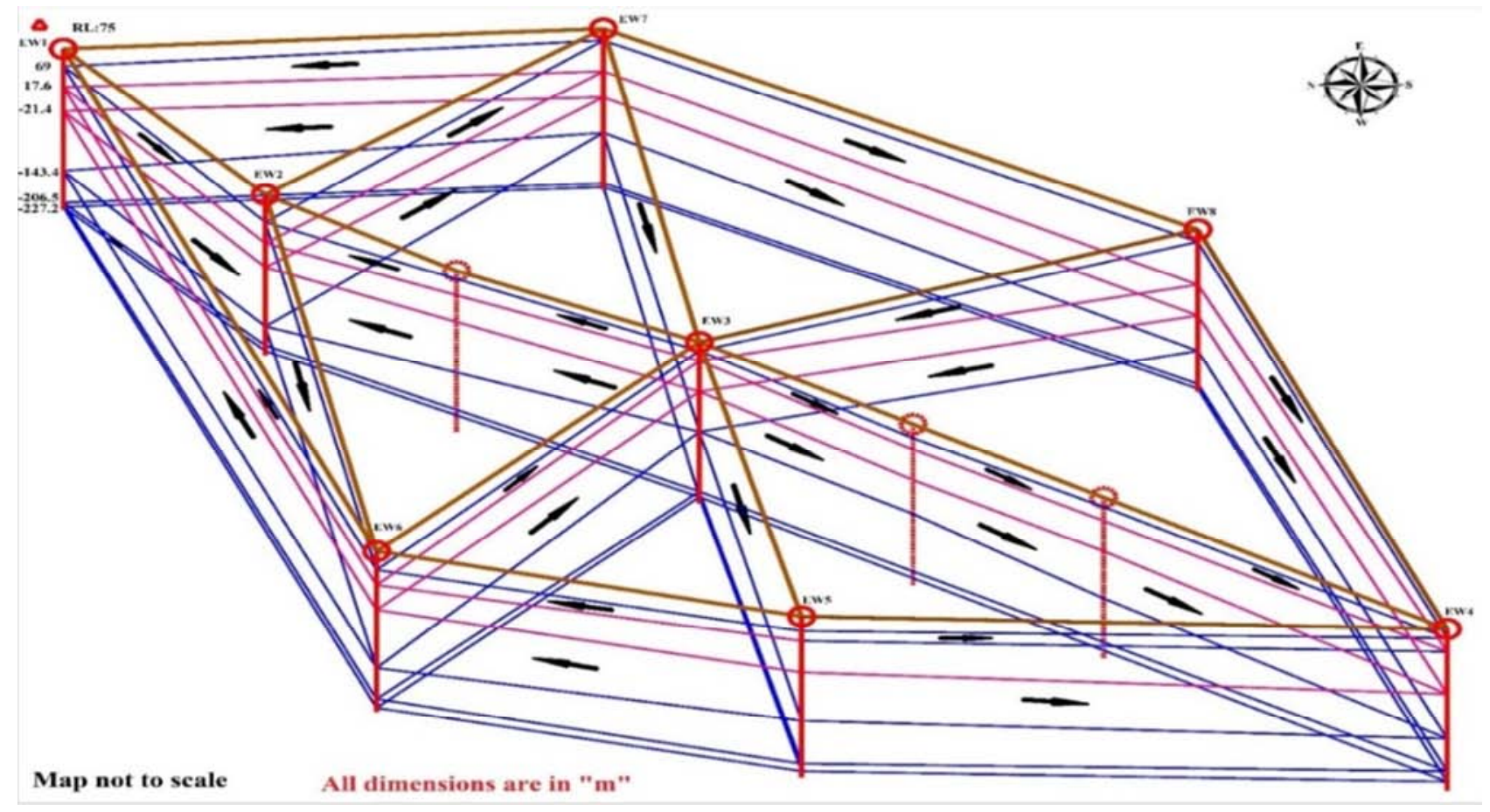

Figure 2. Groundwater flow direction in different aquifers.

Table 3. Discharge Estimation for different FM Scenarios.

\begin{tabular}{llllll}
\hline Bank Full Discharge $\left(\mathbf{m}^{3} / \mathbf{s}\right)$ & $\mathbf{9 0 5}$ & $\mathbf{9 0 5}$ & $\mathbf{9 0 5}$ & $\mathbf{9 0 5}$ \\
\hline SI No. & Flood Management Scenario & I & II & III & IV \\
\hline \multirow{2}{*}{1} & Intra-basin Surface Storage & $25 \%$ & $30 \%$ & $35 \%$ & $40 \%$ \\
& $\left(\mathrm{~m}^{3} / \mathrm{s}\right)$ & 800 & 960 & 1120 & 1280 \\
2 & Intra-basin Surface Transfer & $20 \%$ & $15 \%$ & $10 \%$ & $5 \%$ \\
& $\left(\mathrm{~m}^{3} / \mathrm{s}\right)$ & 640 & 480 & 320 & 160 \\
3 & Inter-basin subsurface Storage & $33 \%$ & $34 \%$ & $35 \%$ & $36 \%$ \\
& $\left(\mathrm{~m}^{3} / \mathrm{s}\right)$ & 1056 & 1088 & 1120 & 1152 \\
$3 \mathrm{~b}$ & Inter-basin subsurface Transfer & $7 \%$ & $6 \%$ & $5 \%$ & $4 \%$ \\
& $\left(\mathrm{~m}^{3} / \mathrm{s}\right)$ & 224 & 192 & 160 & 128 \\
$3 \mathrm{c}$ & Inter-basin surface Storage & $11 \%$ & $10 \%$ & $9 \%$ & $8 \%$ \\
& $\left(\mathrm{~m}^{3} / \mathrm{s}\right)$ & 352 & 320 & 288 & 256 \\
$3 \mathrm{~d}$ & Inter-basin surface Transfer & $4 \%$ & $5 \%$ & $6 \%$ & $7 \%$ \\
\hline
\end{tabular}

\begin{tabular}{llllll}
\hline Bank Full Discharge $\left(\mathbf{m}^{3} / \mathbf{s}\right)$ & 905 & 905 & 905 & 905 \\
\hline SI No. & Flood Management Scenario & I & II & III & IV \\
\hline$\left(\mathrm{m}^{3} / \mathrm{s}\right)$ & 128 & 160 & 192 & 224 \\
Total Historical Peak Discharge $\left(\mathrm{m}^{3} / \mathrm{s}\right)$ & $100 \%$ & $100 \%$ & $100 \%$ & $100 \%$ \\
& 4104 & 4104 & 4104 & 4104 \\
\hline
\end{tabular}

ii. Theim's Equation

Assumptions:

a) Subsurface flow is fully laminar and flow direction in the vicinity of wells is radial.

b) Soil is saturated and homogeneous.

c) Darcy's Law is valid.

For confined aquifer (s), discharge is estimated using Equation 1 and for the unconfined aquifer, discharge formula 
is given by Equation 2 [20]. As the storm duration for the historical peak flood of Sept. 2011 is 10.8 days, it could be possible to select a number of relief wells based on the entire volume -corresponding to Inter-basin subsurface storage as given in Table 4. Here, the historical peak flood hydrograph has been partitioned into different time periods as shown in Figure 3 and volumes corresponding to Inter-basin subsurface storage for different scenarios have been estimated.

$$
\begin{aligned}
& Q=\frac{2 \pi k d\left(h_{1}-h_{2}\right)}{\ln \left(\frac{R}{r_{w}}\right)} \\
& Q=\frac{\pi k\left(h_{1}^{2}-h_{2}^{2}\right)}{\ln \left(\frac{R}{r_{w}}\right)}
\end{aligned}
$$

Table 4. Volume Estimation for different FM Scenarios.

\begin{tabular}{llllll}
\hline SI No. & Flood Management Scenario & I & II & III & IV \\
\hline \multirow{2}{*}{1} & Intra-basin Surface Storage & $25 \%$ & $30 \%$ & $35 \%$ & $40 \%$ \\
& $\left(\mathrm{Mm}^{3}\right)$ & 583.0 & 673.3 & 767.7 & 848.2 \\
2 & Intra-basin Surface Transfer & $20 \%$ & $15 \%$ & $10 \%$ & $5 \%$ \\
& $\left(\mathrm{Mm}^{3}\right)$ & 345.1 & 255.1 & 158.6 & 75.4 \\
\multirow{3}{*}{$3 \mathrm{a}$} & Inter-basin subsurface Storage & $33 \%$ & $34 \%$ & $35 \%$ & $36 \%$ \\
& $\left(\mathrm{Mm}^{3}\right)$ & 318.6 & 325.3 & 332.4 & 339.5 \\
$3 \mathrm{~b}$ & Inter-basin subsurface Transfer $^{3}$ & $7 \%$ & $6 \%$ & $5 \%$ & $4 \%$ \\
& $\left(\mathrm{Mm}^{3}\right)$ & 31.6 & 26.7 & 21.9 & 17.1 \\
$3 \mathrm{c}$ & Inter-basin surface Storage $^{3}$ & $11 \%$ & $10 \%$ & $9 \%$ & $8 \%$ \\
$3 \mathrm{~d}$ & $\left(\mathrm{Mm}^{3}\right)$ & 28.5 & 25.7 & 24.1 & 22.7 \\
& Inter-basin surface Transfer & $4 \%$ & $5 \%$ & $6 \%$ & $7 \%$ \\
\multirow{2}{*}{ Total } & $\left(\mathrm{Mm}^{3}\right)$ & 3.1 & 3.9 & 5.3 & 7.0 \\
& & $100 \%$ & $100 \%$ & $100 \%$ & $100 \%$ \\
\hline
\end{tabular}

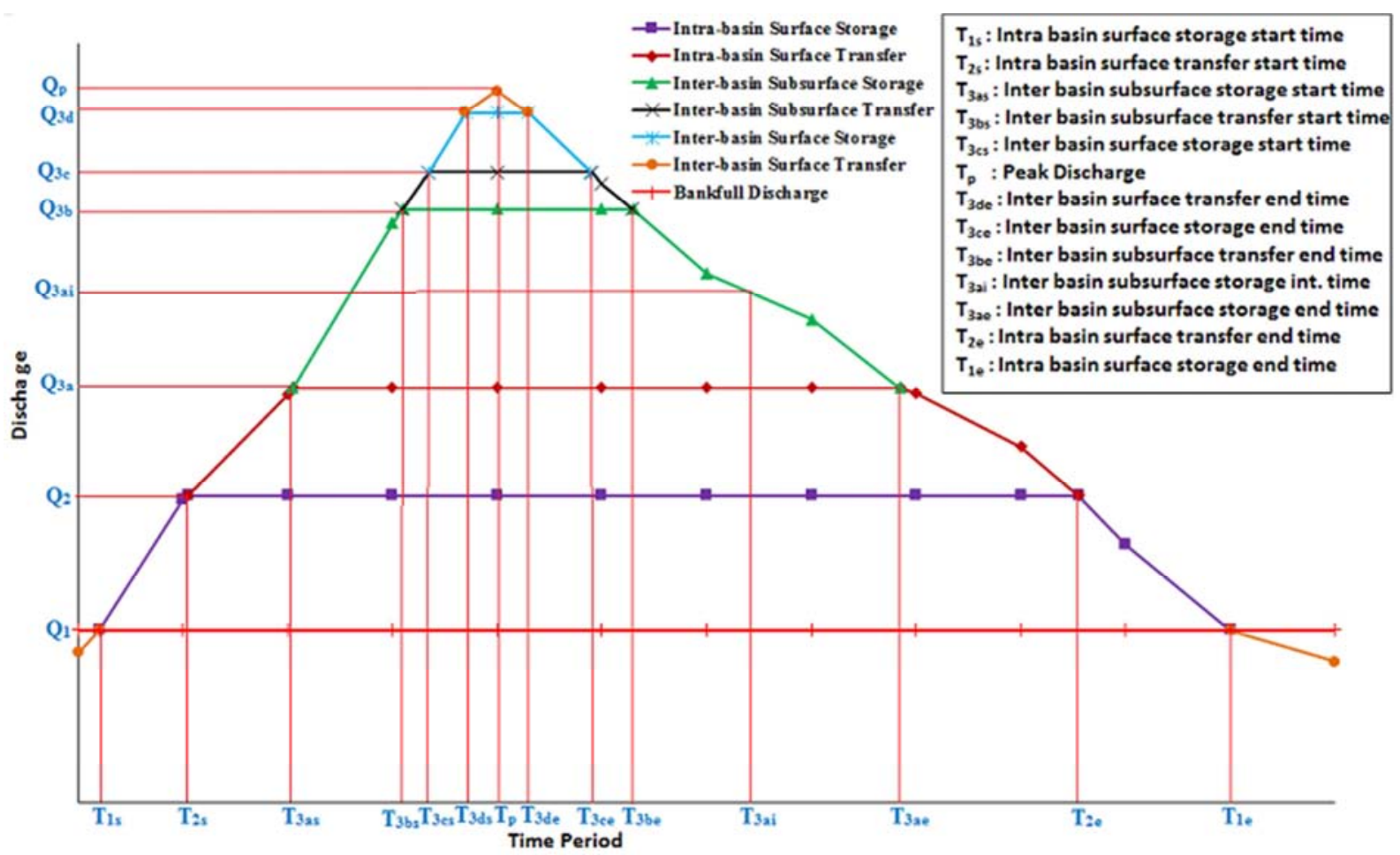

Figure 3. Flood hydrograph for different time period.

\subsubsection{Inter-basin Subsurface Transfer}

Inter-basin subsurface transfer means transferring the surplus flood volume to the neighboring basin (s) through subsurface conduits. Existing facilities available are the interconnected and unconnected aquifers. In the present work, surplus flood volume is proposed to be transferred using subsurface conduits and relief wells (RWs).

A typical case of a 2-directional flow (i.e., water can be transferred from the left RW1 to the right RW3 as well as from the right RW3 to the left RW1) through subsurface conduit (s), as shown in Figure 4. There are two possible cases arising due to 2-directional flow.

Case 1 - For flow towards Relief Well (RW) - 1: The steps involved are as follows:

a) Valves $V_{2 A}, V_{2 B}$ and $V_{1 C}$ need to be closed.

b) Valves $V_{1 A}, V_{1 B}$ and $V_{2 C}$ need to be opened.

c) Pump $\left(\mathrm{P}_{1}\right)$ needs to be operated and Pump $\left(\mathrm{P}_{2}\right)$ needs to be kept idle. 


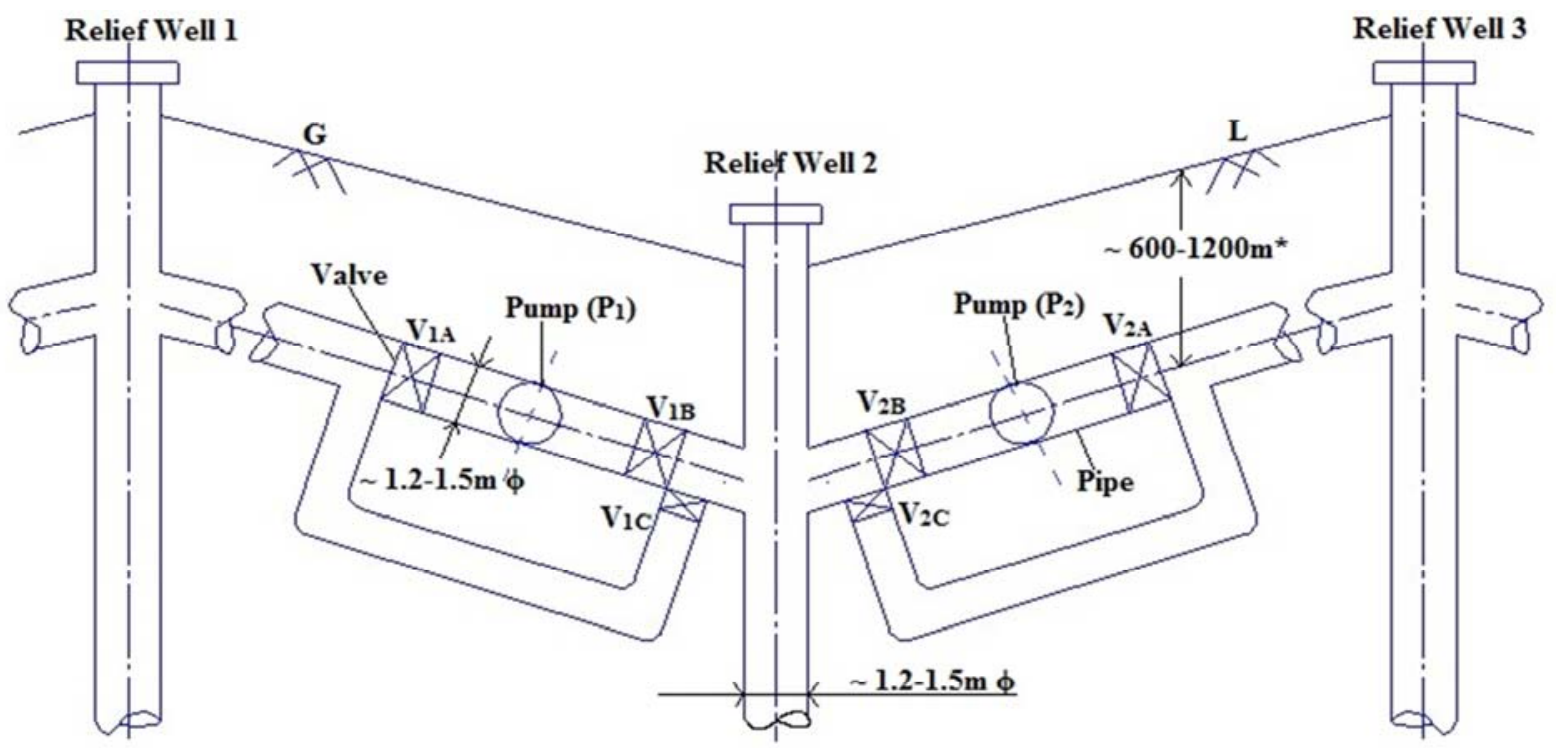

(a)
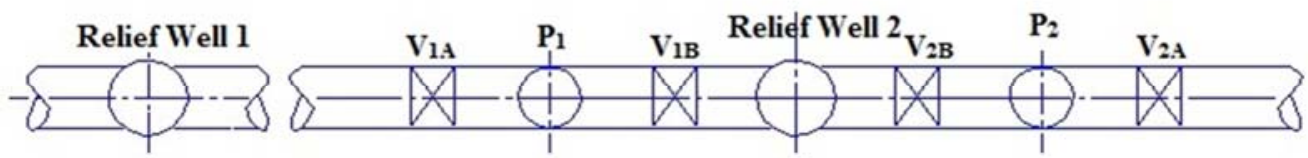

(b)

*Depth to be provided depends upon soil profile

Figure 4. Sketch of flow through subsurface conduit (a) L/S $S^{\text {nal }}$ View (b) Top View.

A typical sketch of the flow towards Relief Well (RW) -1 has been shown in Figure 5.

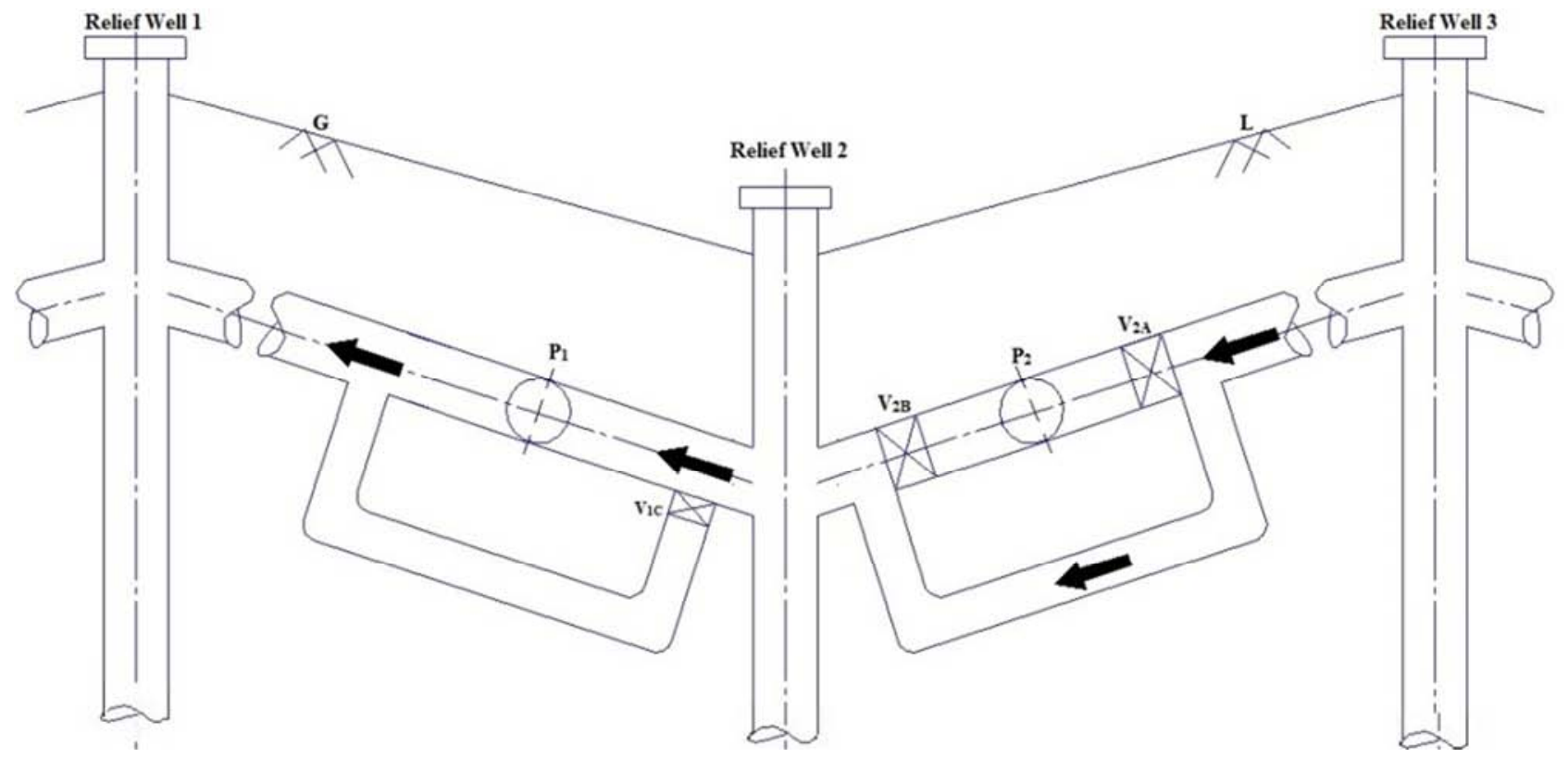

Figure 5. Sketch of the proposed flow towards Relief Well (RW) - 1 to the left.

Case 2 - For flow towards Relief Well (RW) - 3: The steps involved are as follows:

a) Valves $V_{1 A}, V_{1 B}$ and $V_{2 C}$ need to be closed.

b) Valves $V_{2 A}, V_{2 B}$ and $V_{1 C}$ need to be opened.

c) Pump $\left(\mathrm{P}_{2}\right)$ needs to be operated and Pump $\left(\mathrm{P}_{1}\right)$ needs to be kept idle.

A typical sketch of the flow toward Relief Well (RW) - 3 has been shown in Figure 6. 


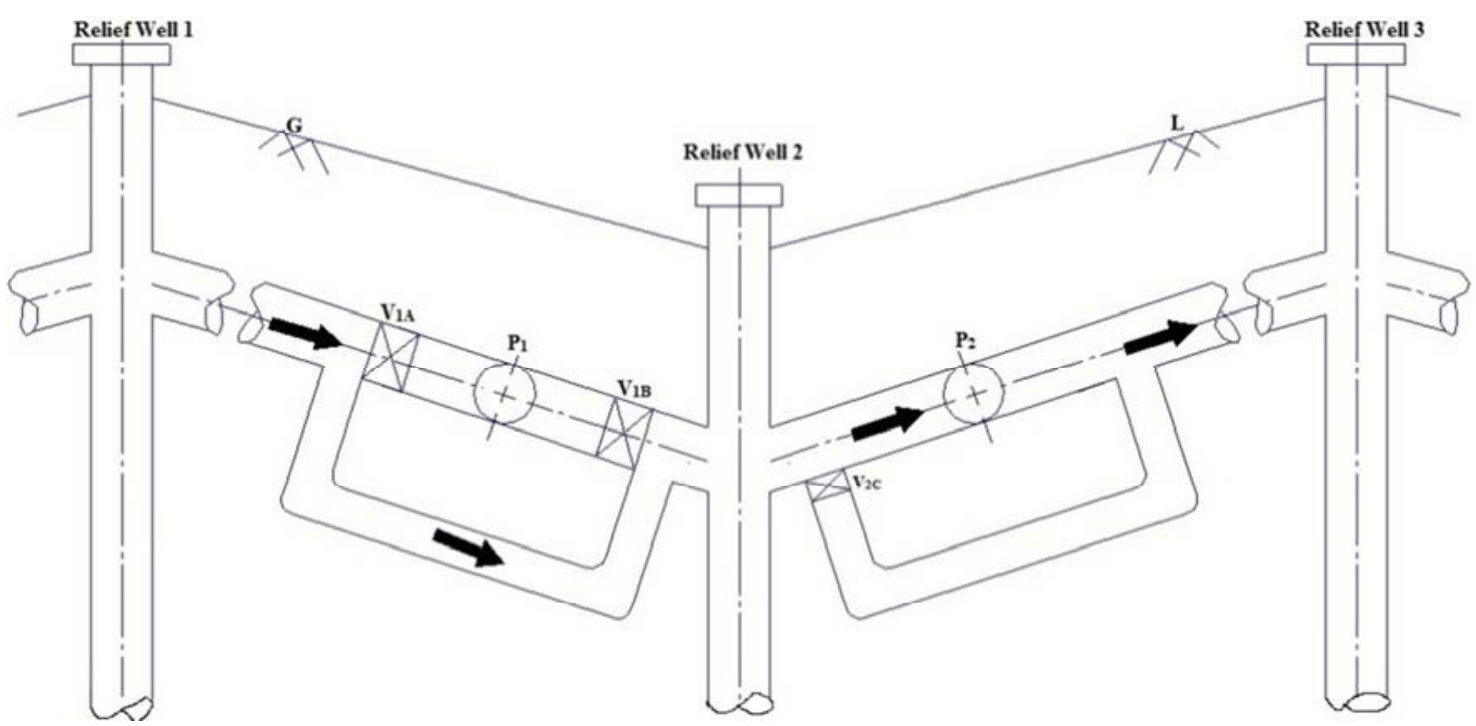

Figure 6. Sketch of the proposed flow towards Relief Well (RW) - 3 to the right.

\subsubsection{Inter-basin Surface Storage}

Inter-basin surface storage means making the surface storage available within a neighboring basin. The existing facilities available are as follows: stream channels, drainage channels, surface depressions and flood plains. The volumes of these existing facilities have been estimated using ArcGIS software. For estimation of stream channel volumes, drainage channel volumes and flood plain volumes, approximate lengths and cross-sections of the channels have been used. For estimation of surface depression volumes, contour maps of $5 \mathrm{~m}$ interval have been used.

After estimating the volumes of surface channels, drainage channels, flood plains and surface depressions, additional inter-basin surface storage could be created using subsurface dykes, relief wells and check dams.

\subsubsection{Inter-basin Surface Transfer:}

Inter-basin surface transfer means transferring the surplus flood water to neighboring basin. The facilities available are stream channels and drainage channels. The volumes of these existing facilities have been estimated using a GIS software. For estimation of stream channel volumes and drainage channel volumes, approximated lengths and cross-sections of the channels have been used.

After estimating the surface channel and drainage channel volumes, additional inter-basin surface transfer capacity could be created using diversion channels and canals. In the present study, some additional flood volume is proposed to be transferred as indicated in Table 11.

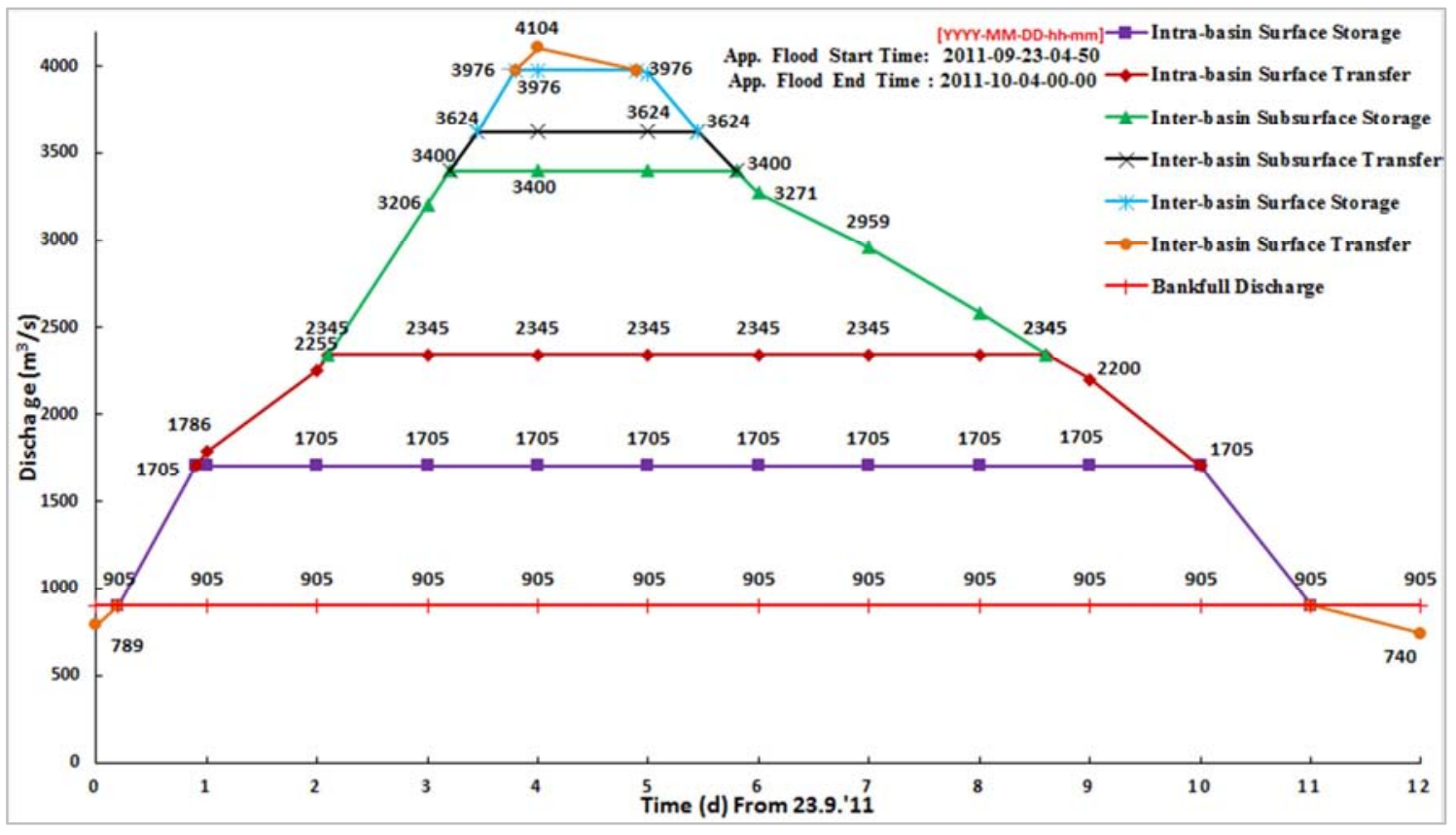

Figure 7. Hydrograph for FM Scenario I. 


\section{Results and Discussion}

\subsection{Flood Management (FM) Scenario}

Hydrographs corresponding to four FM scenarios have been shown in Figures 7 to 10. Discharge and volume corresponding to four FM scenarios have been shown in Table 3 and Table 4 respectively.

\subsection{Inter-basin Subsurface Storage}

Discharge through each aquifer layer of the existing wells have been estimated using Theim's equation for both the unconfined aquifer and confined aquifer (s) as shown in Table 5. After applying the continuity equation, inter-basin subsurface recharge through each of the existing wells have been estimated and are shown in Table 6. For the existing well details, refer to Table 2.

Table 5. Inter-basin subsurface transfer discharge through each aquifer for the existing wells.

\begin{tabular}{|c|c|c|c|}
\hline \multirow{2}{*}{ Flow between Existing Well } & \multicolumn{3}{|c|}{ Discharge $\left(\mathrm{m}^{3} / \mathrm{s}\right)$} \\
\hline & Unconfined & $\mathbf{1}^{\text {st }}$ Confined & $2^{\text {nd }}$ Confined \\
\hline $\mathrm{EW}_{1} \rightarrow \mathrm{EW}_{2}$ & 0.11 & 0.37 & 0.05 \\
\hline $\mathrm{EW}_{6} \rightarrow \mathrm{EW}_{1}$ & 0.08 & 1.10 & 0.23 \\
\hline $\mathrm{EW}_{2} \rightarrow \mathrm{EW}_{7}$ & 0.02 & 0.18 & 0.02 \\
\hline $\mathrm{EW}_{3} \rightarrow \mathrm{EW}_{2}$ & 0.08 & 2.03 & 0.10 \\
\hline $\mathrm{EW}_{8} \rightarrow \mathrm{EW}_{3}$ & 0.41 & 0.85 & 0.24 \\
\hline $\mathrm{EW}_{3} \rightarrow \mathrm{EW}_{4}$ & 0.09 & 0.20 & 0.08 \\
\hline $\mathrm{EW}_{2} \rightarrow \mathrm{EW}_{6}$ & 0.06 & 1.08 & 0.02 \\
\hline $\mathrm{EW}_{7} \rightarrow \mathrm{EW}_{3}$ & 0.30 & 1.44 & 0.09 \\
\hline $\mathrm{EW}_{3} \rightarrow \mathrm{EW}_{5}$ & 0.73 & 0.40 & 0.12 \\
\hline $\mathrm{EW}_{6} \rightarrow \mathrm{EW}_{3}$ & 0.24 & 0.63 & 0.68 \\
\hline $\mathrm{EW}_{8} \rightarrow \mathrm{EW}_{4}$ & 0.20 & 1.05 & 0.28 \\
\hline $\mathrm{EW}_{7} \rightarrow \mathrm{EW}_{1}$ & 0.05 & 0.15 & 0.03 \\
\hline $\mathrm{EW}_{5} \rightarrow \mathrm{EW}_{6}$ & 0.08 & 1.24 & 0.78 \\
\hline
\end{tabular}

As the historical peak flood has a duration of 10.8 days, it would not be proper to select a number of relief wells based on the entire volume corresponding to inter-basin subsurface storage. Hence, the flood hydrograph considered here has been divided into different time periods and volumes corresponding to inter-basin subsurface storage for different scenarios have been estimated as shown in Table 7. Refer to Figure 4 for the legend for all the time period notations.

Table 6. Inter-basin subsurface recharge through each of the Existing Wells.

\begin{tabular}{lllll}
\hline \multirow{2}{*}{ Existing Well $(\mathbf{E W})$} & \multicolumn{2}{l}{ Recharge $\left(\mathbf{m}^{\mathbf{3}} / \mathbf{s}\right)$} & & Total Recharge $\left(\mathbf{m}^{\mathbf{3}} / \mathbf{s}\right)$ \\
\cline { 2 - 5 } & Unconfined & $\mathbf{1}^{\text {st }}$ Confined & $\mathbf{2}^{\text {nd }}$ Confined & 1.10 \\
\hline$E W_{1}$ & 0.02 & 0.87 & 0.21 & 1.37 \\
$E W_{2}$ & 0.11 & 1.14 & 0.11 & 1.06 \\
$E W_{3}$ & 0.06 & 0.29 & 0.71 & 2.88 \\
$E W_{4}$ & 0.52 & 1.82 & 0.54 & 1.24 \\
$E W_{5}$ & 0.73 & 0.40 & 0.12 & 2.55 \\
$E W_{6}$ & 0.41 & 1.43 & 0.71 & 1.31 \\
$E W_{7}$ & 0.65 & 0.24 & 0.42 & 2.31 \\
\hline
\end{tabular}

Table 7. Volume distribution for FM Scenario I during different time periods.

\begin{tabular}{|c|c|c|c|c|c|}
\hline \multicolumn{2}{|c|}{ Time Period } & \multicolumn{4}{|c|}{ Inter basin subsurface Storage $\left(\mathrm{Mm}^{3}\right)$} \\
\hline Notation & in $\mathrm{hr}$ & Scenario I & Scenario II & Scenario III & Scenario IV \\
\hline $\mathrm{T}_{3 \mathrm{bs}}$ & 3.10 & 47.1 & 48.1 & 49.1 & 50.2 \\
\hline $\mathrm{T}_{3 \mathrm{cs}}$ & 3.35 & 14.9 & 15.2 & 15.5 & 15.9 \\
\hline $\mathrm{T}_{3 \mathrm{ds}}$ & 3.70 & 28.5 & 29.1 & 29.7 & 30.4 \\
\hline $\mathrm{T}_{\mathrm{p}}$ & 4.00 & 13.6 & 13.9 & 14.2 & 14.5 \\
\hline $\mathrm{T}_{3 \mathrm{de}}$ & 4.30 & 55.8 & 57.0 & 58.2 & 59.4 \\
\hline $\mathrm{T}_{3 \mathrm{ce}}$ & 4.90 & 31.0 & 31.6 & 32.3 & 33.0 \\
\hline $\mathrm{T}_{3 \mathrm{be}}$ & 5.30 & 27.3 & 27.8 & 28.5 & 29.1 \\
\hline $\mathrm{T}_{3 \mathrm{ai}}$ & 6.16 & 57.0 & 58.2 & 59.5 & 60.8 \\
\hline $\mathrm{T}_{3 \mathrm{ae}}$ & 7.85 & 43.4 & 44.3 & 45.3 & 46.2 \\
\hline Total & & 318.6 & 325.3 & 332.4 & 339.5 \\
\hline
\end{tabular}

In the table $7, \mathrm{~T}_{3 \mathrm{bs}}$ is inter basin subsurface transfer start time, $T_{3 \mathrm{cs}}$ is inter basin surface storage start time, $T_{3 \mathrm{ds}}$ is inter basin surface transfer start time, $T_{p}$ is peak discharge time, $T_{3 \text { de }}$ is inter basin surface transfer end time, $\mathrm{T}_{3 \mathrm{ce}}$ is inter basin surface storage end time, $\mathrm{T}_{3 \mathrm{be}}$ is inter basin subsurface transfer end time, $\mathrm{T}_{3 \mathrm{ai}}$ is inter basin subsurface storage intermediate 
time and $\mathrm{T}_{3 \mathrm{ae}}$ is inter basin subsurface storage end time.

Maximum volume corresponding to inter-basin subsurface storage for each of the FM scenario have been considered for further analysis. Based on the maximum volume, estimation of the required number of relief wells have been done. Recharge estimation through these proposed relief wells are shown in Table 8 .

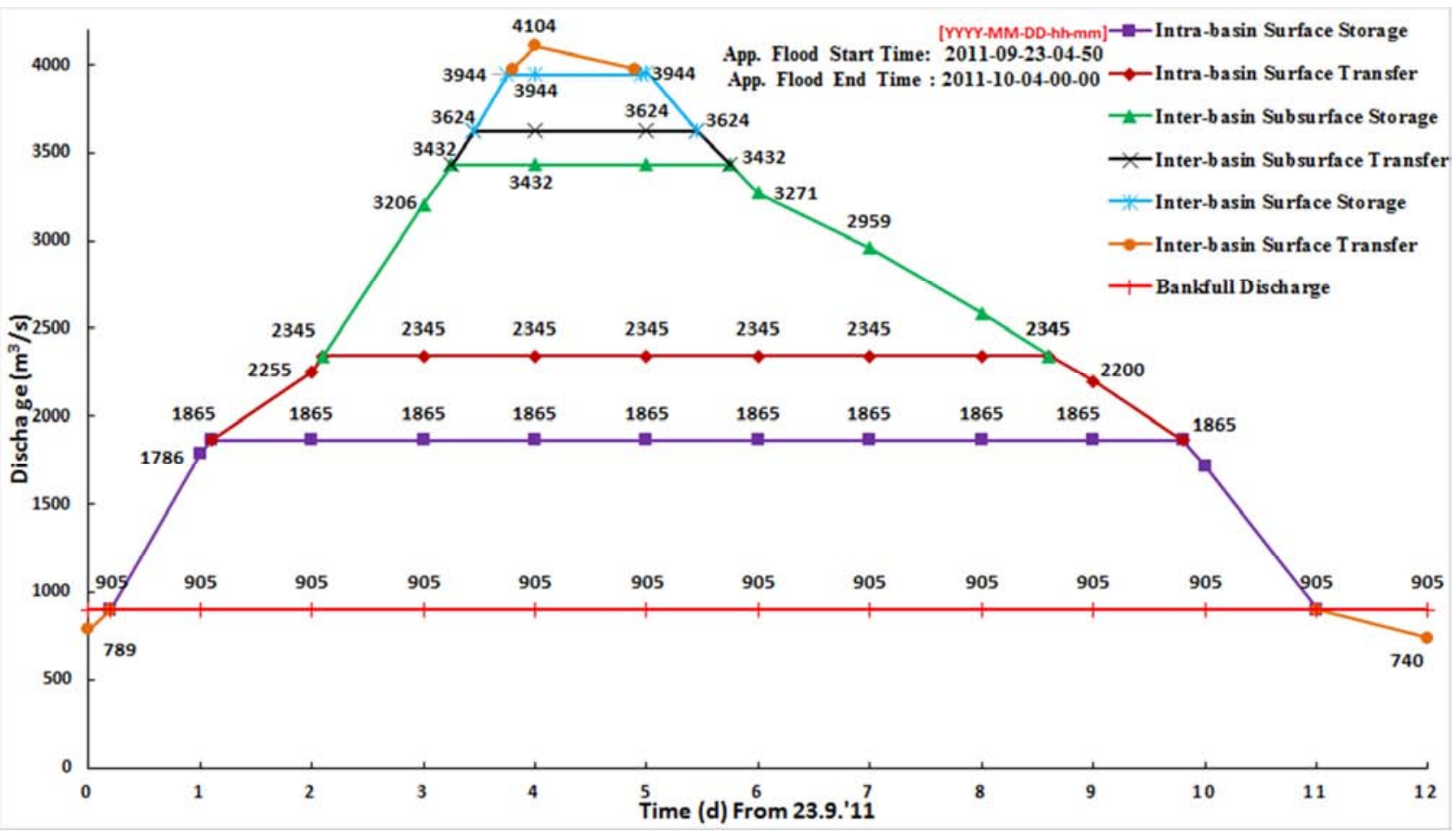

Figure 8. Hydrograph for FM Scenario II.

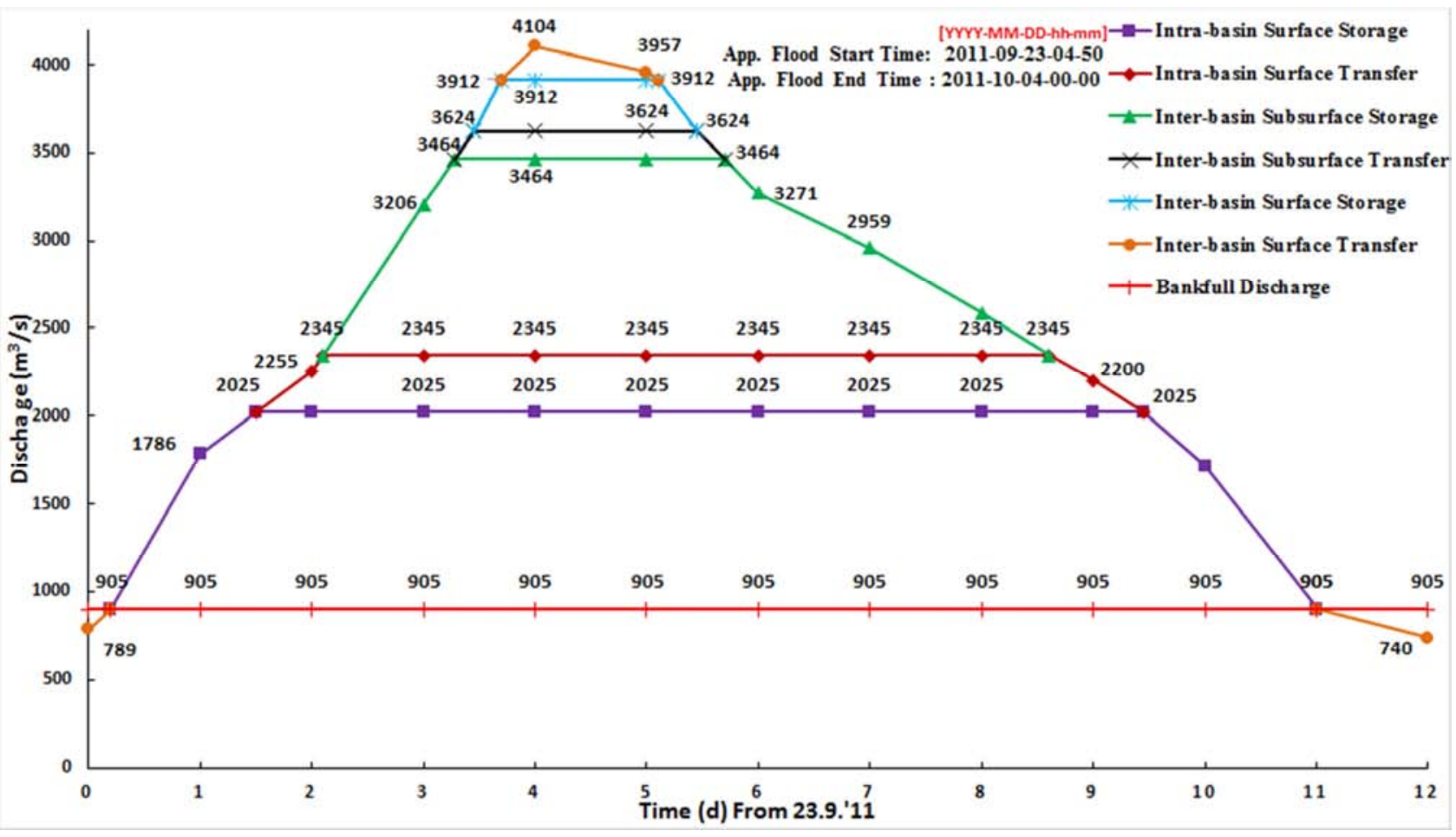

Figure 9. Hydrograph for FM Scenario III. 


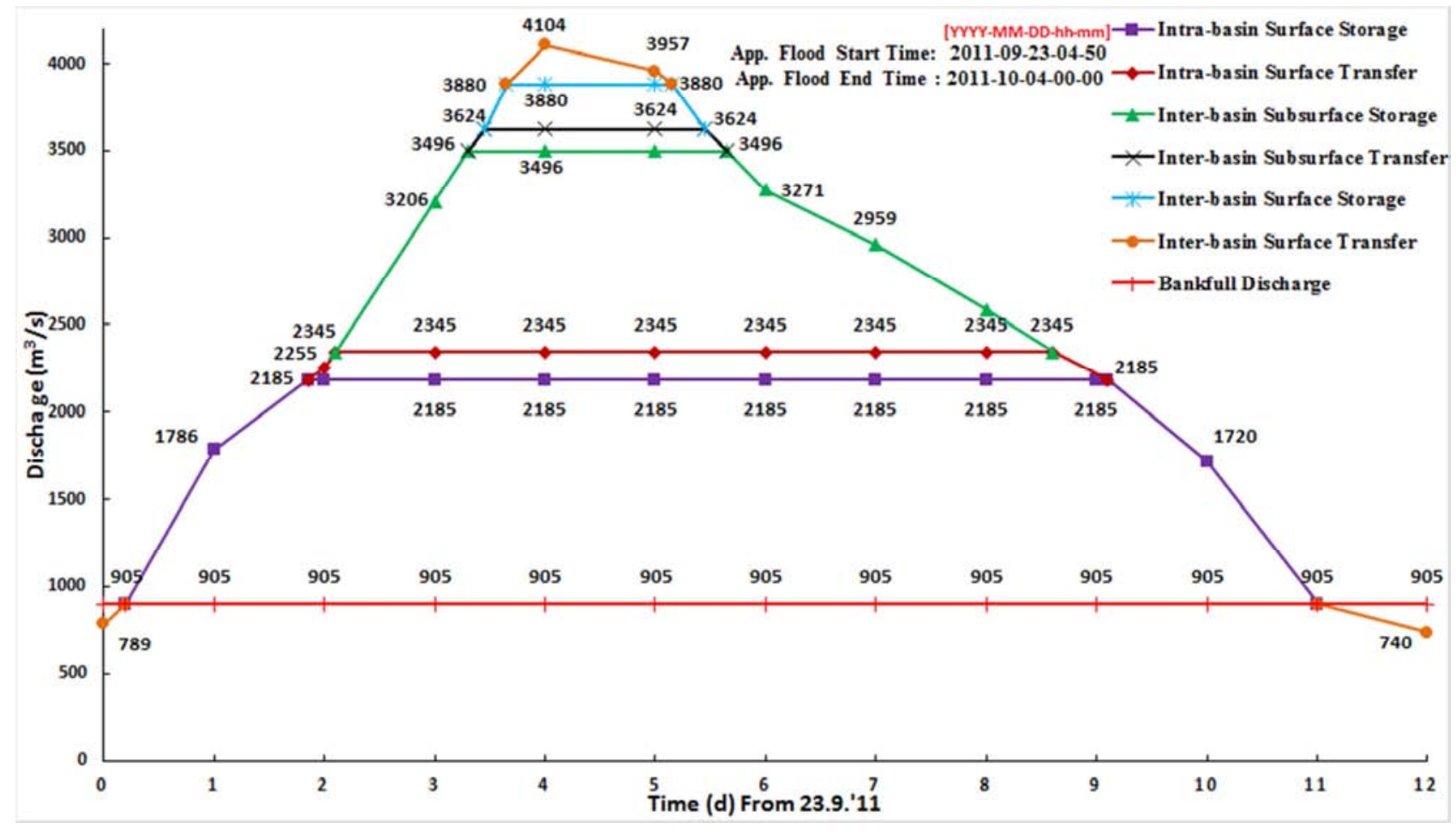

Figure 10. Hydrograph for FM Scenario IV.

Table 8. Recharge estimation through proposed relief wells.

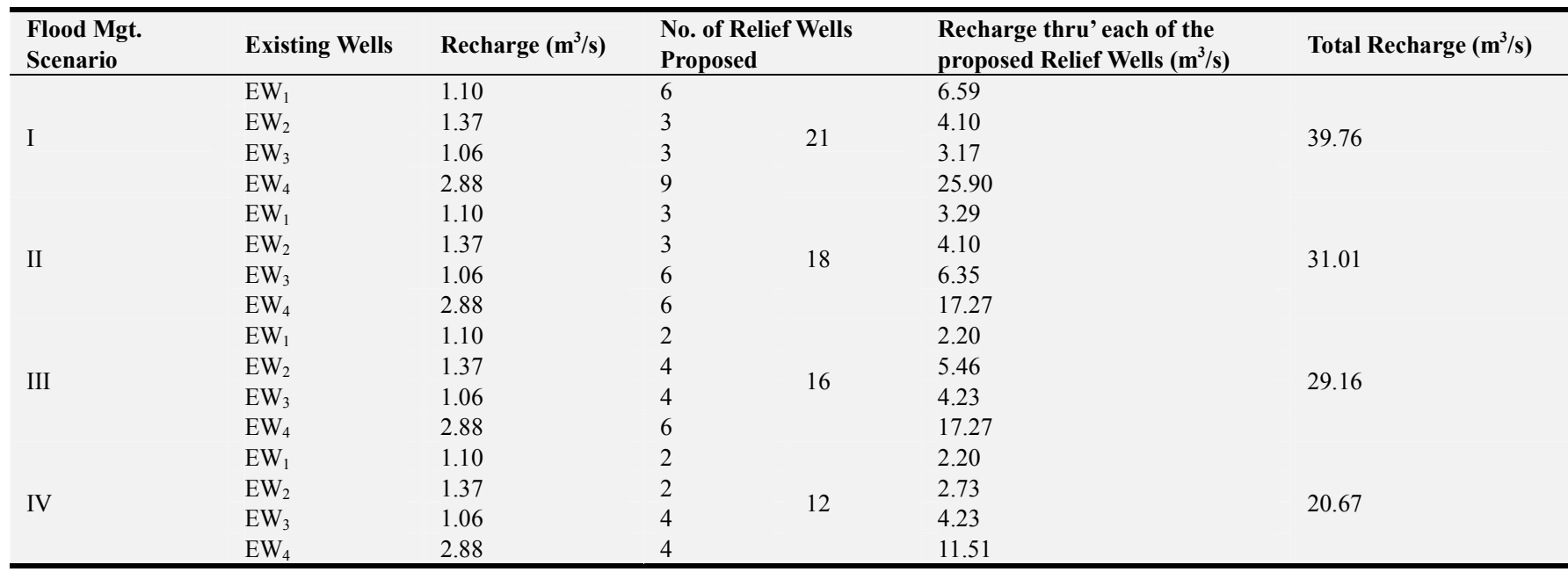

Inter-basin subsurface storage volume has been estimated as product of recharge and historical Peak Flood Duration. Interbasin subsurface storage volume estimation for all the FM scenarios have been shown in Table 9.

Table 9. Inter-basin subsurface storage volume estimation.

\begin{tabular}{|c|c|c|c|c|}
\hline $\begin{array}{l}\text { Flood Mgt. } \\
\text { Scenario }\end{array}$ & $\begin{array}{l}\text { Required Subsurface Storage } \\
\left(\mathrm{Mm}^{3}\right)\end{array}$ & $\begin{array}{l}\text { Recharge }\left(Q_{r}\right) \\
\left(\mathbf{m}^{3} / \mathbf{s}\right)\end{array}$ & Historical Peak Storm Duration (d) & Estimated Volume $\left(\mathrm{Mm}^{3}\right)$ \\
\hline I & 57.00 & 39.76 & 10.8 & 37.10 \\
\hline II & 58.20 & 31.01 & 10.8 & 28.93 \\
\hline IV & 60.80 & 20.67 & 10.8 & 19.29 \\
\hline
\end{tabular}

\subsection{Intra-basin/Inter-basin Surface Storage/Transfer}

Contour map of $5 \mathrm{~m}$ interval, topo-sheets and drainage channels \& stream channels of the study area have been shown in Figures 11 to 13. Estimation of existing surface storage and estimation of volume to be created have been shown in Tables 10 and 11 respectively. 


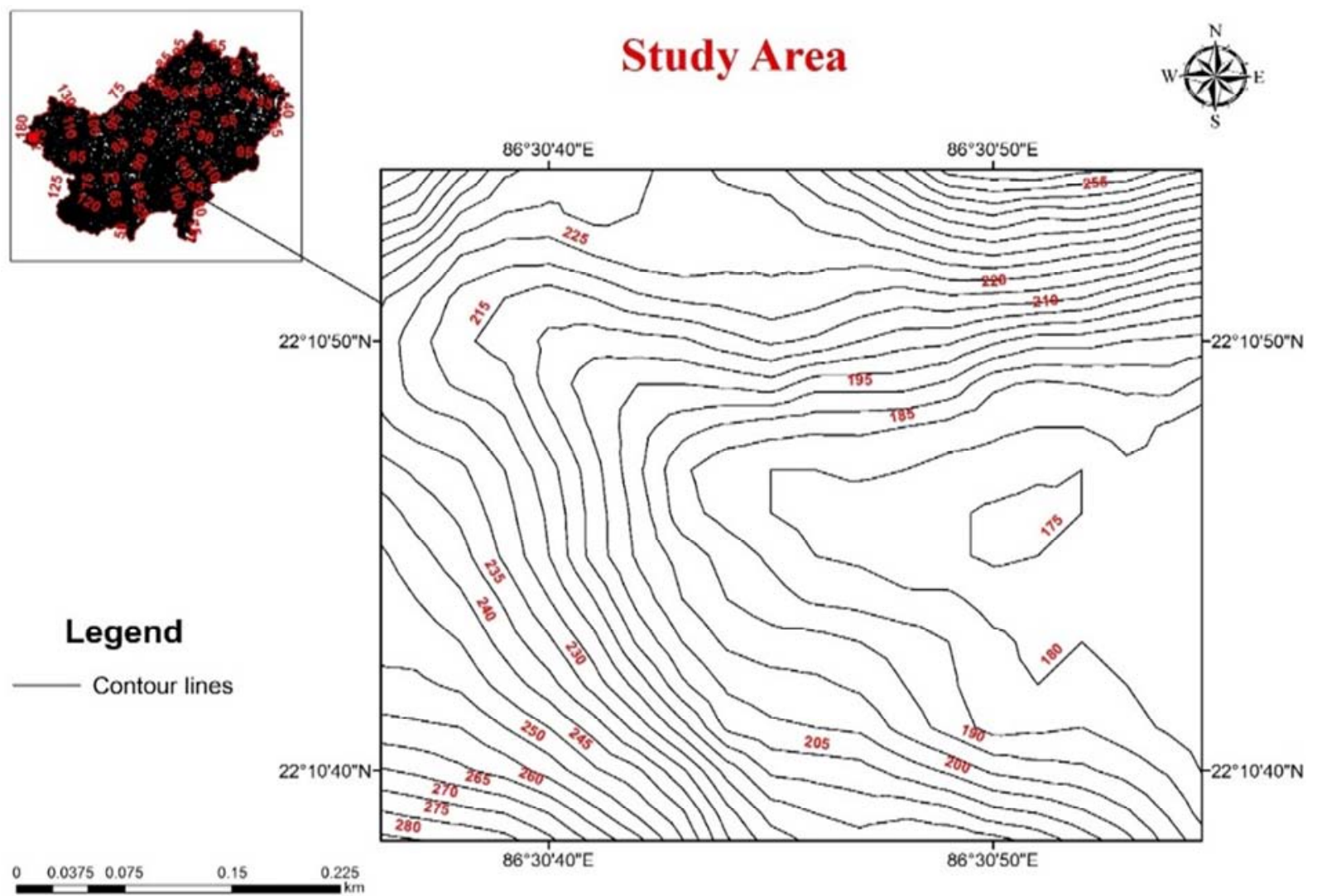

Figure 11. Contour Map of the Study area at 5 m contour interval.

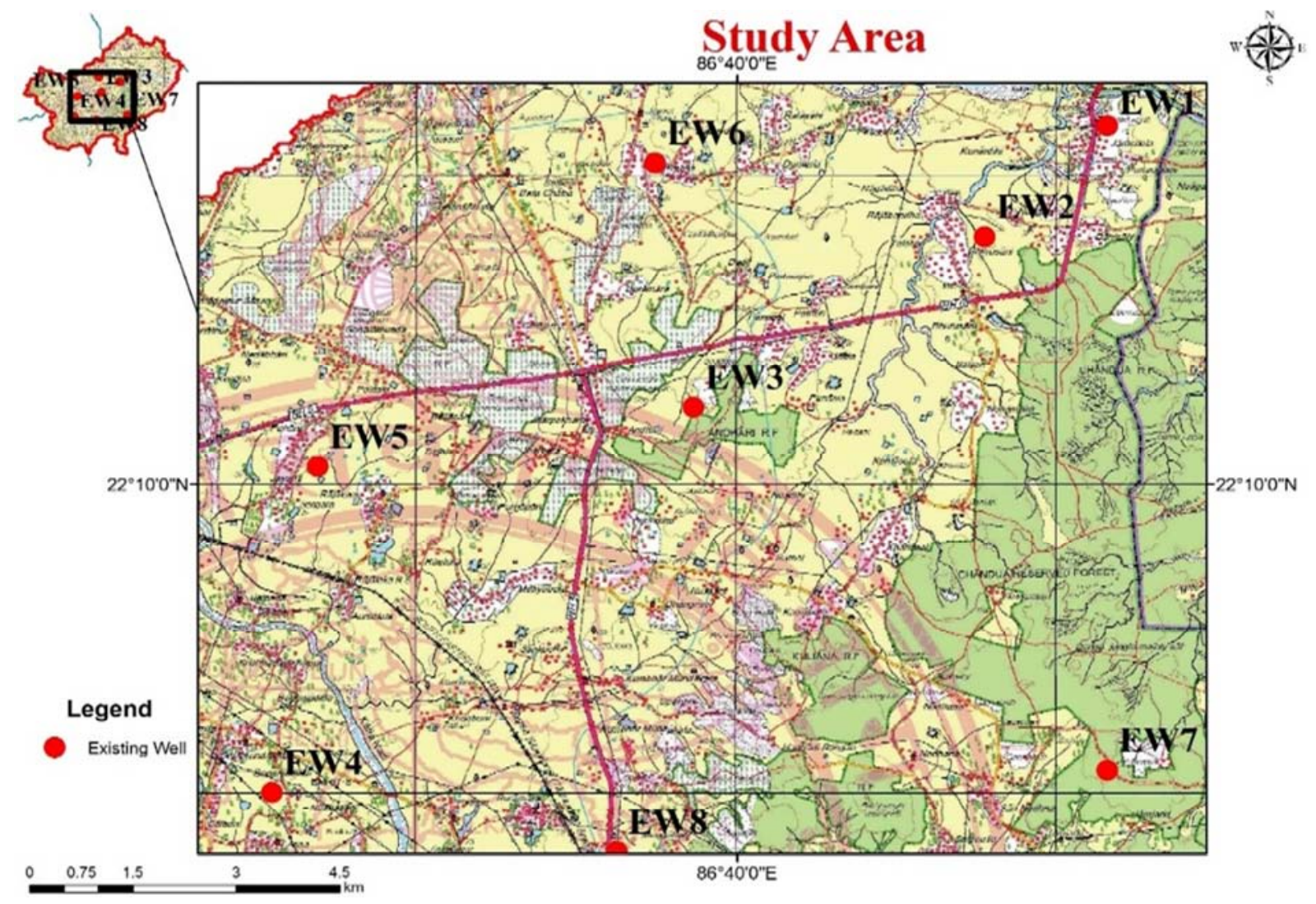

Figure 12. Toposheets for the Study area with Existing wells (EWs). 


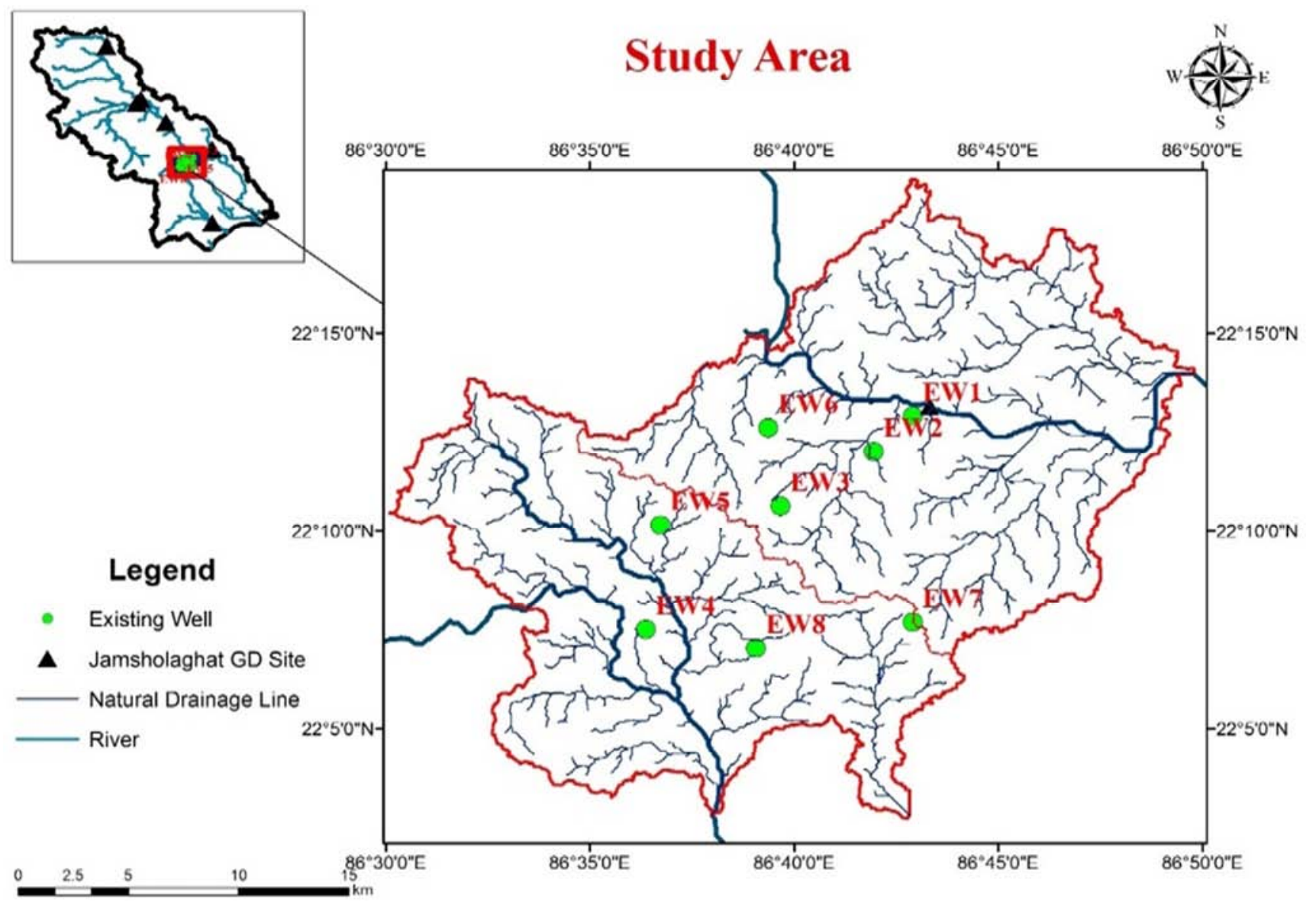

Figure 13. Drainage channels and Stream Channels in the Study area with Existing wells (EWs).

Table 10. Estimation of existing surface storage.

\begin{tabular}{lll}
\hline Surface Storage Available & Inter-basin Surface Storage $\left(\mathbf{M m}^{\mathbf{3}}\right)$ & Intra-basin Surface $\mathbf{S t o r a g e ~}\left(\mathbf{M m} \mathbf{3}^{\mathbf{3}}\right)$ \\
\hline Flood Plains \& Depressions & 120.32 & 152.48 \\
Stream Channels & 278.65 & - \\
Other Drainage Channels & 131.56 & 151.25 \\
Total Existing Surface Storage & 834.26 & \\
\hline
\end{tabular}

Table 11. Estimation of additional flood volume to be created.

\begin{tabular}{|c|c|c|c|c|}
\hline FM Scenario & I & II & III & IV \\
\hline Intra-basin and Inter-basin Surface Storage $\left(\mathrm{Mm}^{3}\right)$ & 583.0 & 673.3 & 767.7 & 848.2 \\
\hline Intra-basin and Inter-basin Surface Transfer $\left(\mathrm{Mm}^{3}\right)$ & 348.2 & 259.0 & 163.9 & 82.5 \\
\hline Total Flood Volume $\left(\mathrm{Mm}^{3}\right)$ & 931.2 & 932.3 & 931.6 & 930.7 \\
\hline Total Existing Surface Storage $\left(\mathrm{Mm}^{3}\right)$ & 834.3 & 834.3 & 834.3 & 834.3 \\
\hline Additional Flood Volume to be Created $\left(\mathrm{Mm}^{3}\right)$ & 96.9 & 98.0 & 97.3 & 96.4 \\
\hline
\end{tabular}

In order to create the additional flood volume, relief wells are being proposed. Estimation of total recharge through proposed relief wells and estimated recharge volume for all the scenarios have been shown in Table 12 and Table 13. Locations of the proposed relief wells (PWs) around the Existing wells (EWs) have been shown in Figure 14.

Table 12. Estimation of total recharge volume through all the proposed relief wells.

\begin{tabular}{llllll}
\hline $\begin{array}{l}\text { Flood Mgt. } \\
\text { Scenario }\end{array}$ & Existing Wells & Recharge $\left(\mathbf{m}^{3} / \mathbf{s}\right)$ & $\begin{array}{l}\text { No. of Relief Wells } \\
\text { Proposed }\end{array}$ & $\begin{array}{l}\text { Recharge thru' proposed } \\
\text { Relief Wells }\left(\mathbf{m}^{3} / \mathbf{s}\right)\end{array}$ & $\begin{array}{l}\text { Total Recharge thru' } \\
\text { Proposed Relief Wells }\left(\mathbf{m}^{3} / \mathbf{s}\right)\end{array}$ \\
\hline & EW5 & 1.24 & 5 & 6.22 & 41.89 \\
I, II, III and IV & EW6 & 2.55 & 6 & 22 & 15.28 \\
& EW7 & 1.31 & 5 & & 6.54 \\
& EW8 & 2.31 & 6 & 13.85 & \\
\hline
\end{tabular}


Table 13. Estimation of additional recharge volume through proposed relief well.

\begin{tabular}{lllll}
\hline $\begin{array}{l}\text { Flood Mgt. } \\
\text { Scenario }\end{array}$ & $\begin{array}{l}\text { Flood Volume to be } \\
\text { Managed }\left(\mathbf{M m}^{\mathbf{3}}\right)\end{array}$ & $\begin{array}{l}\text { Recharge thru' proposed } \\
\text { Relief Wells } \mathbf{( \mathbf { m } ^ { 3 } / \mathbf { s } )}\end{array}$ & $\begin{array}{l}\text { Historical Peak Storm } \\
\text { Duration }(\mathbf{d})\end{array}$ & $\begin{array}{l}\text { Estimated Recharge Volume } \\
\left(\mathbf{M m}^{\mathbf{3}}\right)\end{array}$ \\
\hline I & 96.95 & 41.89 & 10.8 & 39.09 \\
II & 98.00 & 41.89 & 10.8 & 39.09 \\
III & 97.30 & 41.89 & 10.8 & 39.09 \\
IV & 96.43 & 41.89 & 10.8 & 39.09 \\
\hline
\end{tabular}

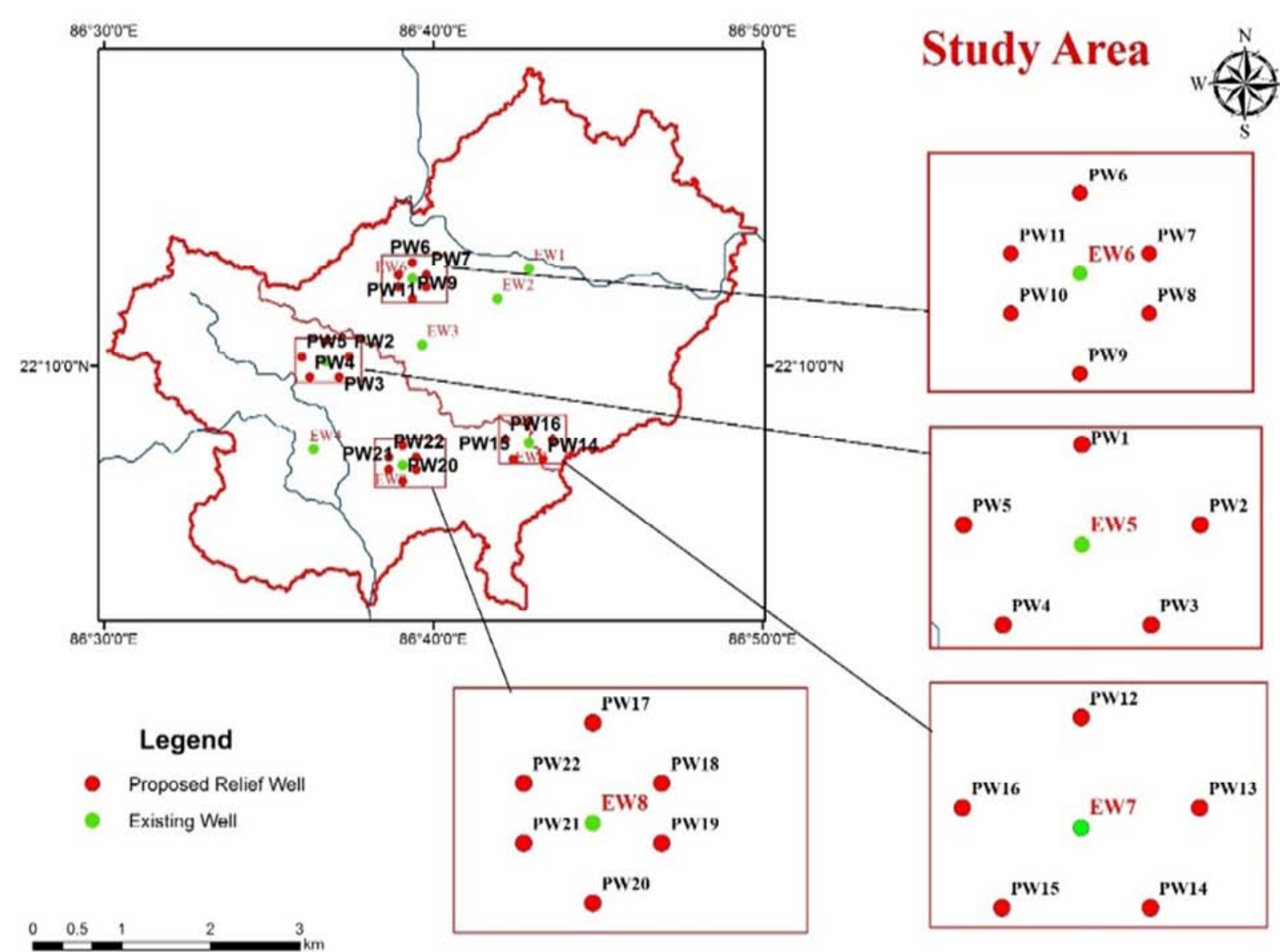

Figure 14. Proposed relief wells (PWs) around the Existing wells (EWs).

\subsection{Inter-basin Subsurface Transfer}

Assumptions: As per the Bureau of Indian Standards (BIS) Code of Practice 4880 (1976), the cross-sectional average velocity (V) through the subsurface transfer conduits has been considered as $7.5 \mathrm{~m} / \mathrm{s}$ and circular channel crosssections have been proposed [21]. Discharge formula is given by Equation 3.

$$
Q_{3 b}-Q_{r}=\frac{\pi D^{2}}{4} \times V \times n
$$

Where, $Q_{3 b}$ is inter-basin subsurface transfer discharge, $Q_{r}$ is recharge, $\mathrm{D}$ is the diameter of subsurface conduit, $\mathrm{V}$ is the velocity and $n$ is the number of subsurface conduits. The estimation of diameter and the number of subsurface conduits required to transfer the additional flood volume from Subarnarekha basin to Burhabalang basin through subsurface transfer conduits has been shown in Table 14. The top view of the proposed subsurface conduits along with the proposed relief wells for all the Flood Management (FM) scenarios have been shown in Figures 15 to 18 .

Table 14. Details of the circular inter-basin subsurface transfer.

\begin{tabular}{|c|c|c|c|c|}
\hline $\begin{array}{l}\text { Flood Mgt. } \\
\text { Scenario }\end{array}$ & $\begin{array}{l}\text { Inter-basin Subsurface Transfer } \\
\text { Discharge, } \mathbf{Q}_{3 \mathrm{~b}}\left(\mathrm{~m}^{3} / \mathbf{s}\right)\end{array}$ & $\begin{array}{l}\text { Recharge through } \\
\text { relief well, } Q_{\mathrm{r}}\left(\mathrm{m}^{3} / \mathrm{s}\right)\end{array}$ & $\begin{array}{l}\text { No. of Required Subsurface } \\
\text { Transfer Conduits, } \mathbf{n}\end{array}$ & $\begin{array}{l}\text { Dia. of Circular Subsurface } \\
\text { Transfer Conduit, D (m) }\end{array}$ \\
\hline I & 224 & 39.76 & 3 & 3.2 \\
\hline II & 192 & 31.01 & 3 & 3.0 \\
\hline III & 160 & 29.16 & 2 & 3.3 \\
\hline IV & 128 & 20.67 & 2 & 3.0 \\
\hline
\end{tabular}




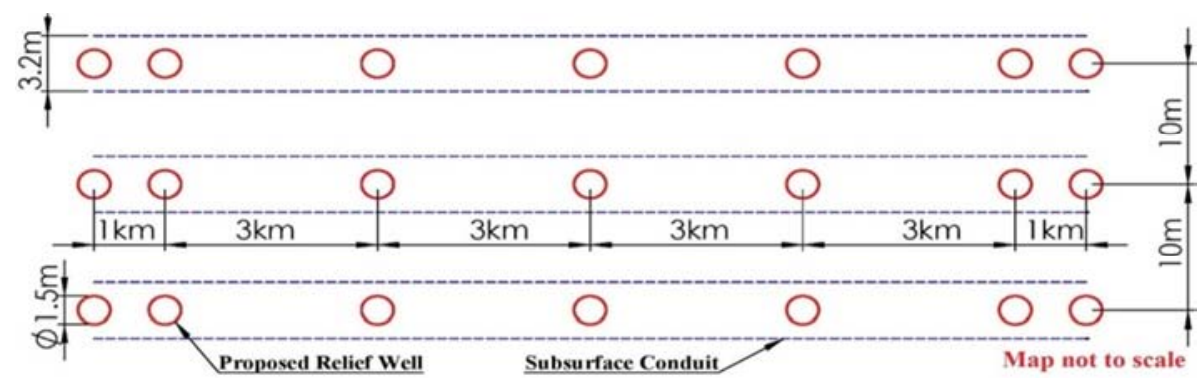

Figure 15. Top view for FM Scenario I.

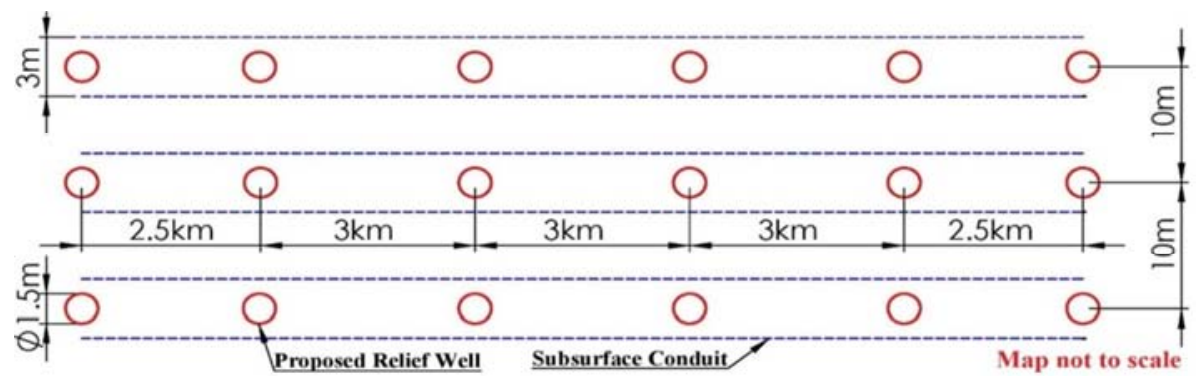

Figure 16. Top view for FM Scenario II.
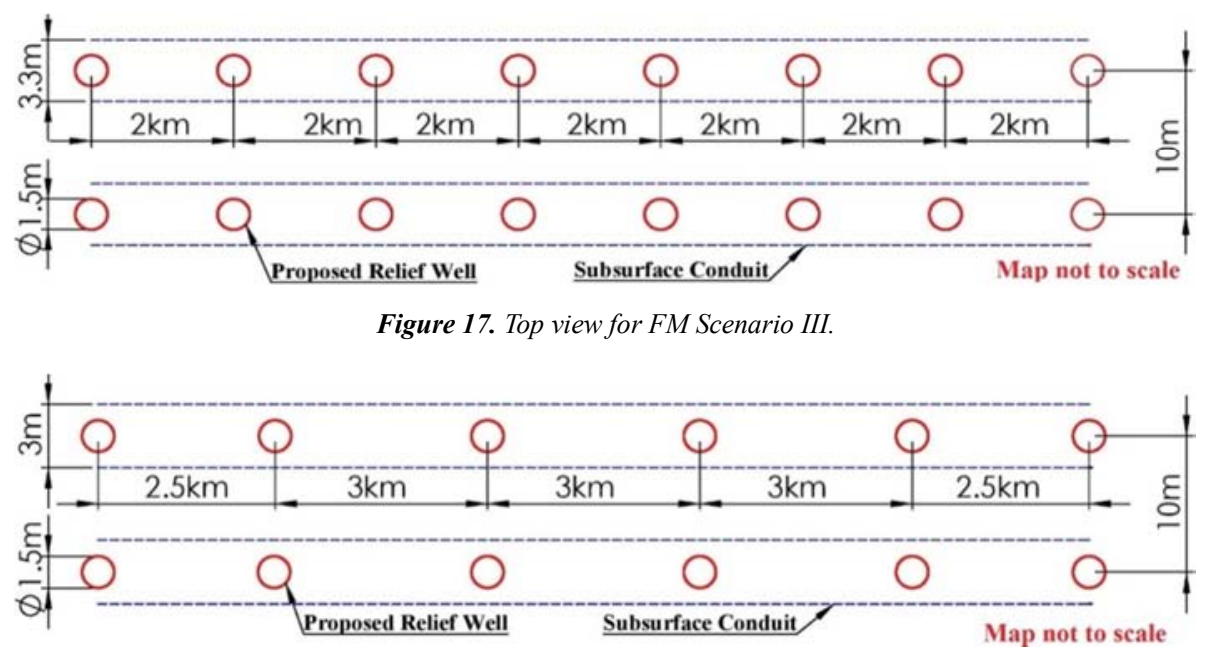

Figure 18. Top view for FM Scenario IV.

In the present study, relief wells and subsurface flow conduits have been used extensively as viable FM techniques. Relief wells may be substituted by check dams of suitable recharge and storage capacity.

\section{Conclusions}

In the detailed analysis of all the broad FM techniques along with the different FM scenarios have been carried out. The following conclusions are drawn, based on this study:

a) Among the various FM techniques, topmost priority has been given to intra-basin storage/transfer techniques rather than the inter-basin storage/transfer techniques and within them high priority has been given to storage rather than transfer.

b) In the historical peak flood hydrograph considered for different FM scenarios, various FM techniques have been proposed through horizontal lines, so as to make the operation simple and to ensure a steady discharge for a longer duration of time within the entire flood duration.

c) Out of all the four FM scenarios considered and detailed in Table 1, FM scenario I is the best scenario for storage $(69 \%)$ and the worst scenario for transfer (31\%), whereas FM scenario IV is the best scenario for transfer $(16 \%)$ and the worst scenario for storage (84\%).

d) In case of inter-basin subsurface transfer for different FM scenarios, the number and the diameter of the proposed subsurface conduits is ranging between 2 - 3 and between $2.8 \mathrm{~m}$ to $3.1 \mathrm{~m}$ respectively.

e) In case of inter-basin subsurface transfer for different FM scenarios, the subsurface conduits are proposed to be placed at a center to center spacing of $10 \mathrm{~m}$ across the subsurface transfer direction.

f) In case of intra-basin/inter-basin surface storage/transfer, some of the proposed relief wells may be substituted by 
check dams with suitable recharge and storage capacities.

\section{References}

[1] Bandyopadhyaya J. and Perveen S. (2003). The Interlinking of Indian Rivers: Proceedings of the Seminar on Interlinking Indian Rivers: Bane or Boon?, Indian Institute of Social Welfare \& Business Management (IISWBM), Kolkata, West Bengal, India, June, School of Oriental and African Studies (SOAS) Water Issues Study Group, Occasional, 60.

[2] Rao K. L. (1975). India's Water Wealth - Its Assessment, Uses and Projections, Orient Longman Ltd., Hyderabad, formerly in Andhra Pradesh, India.

[3] Integrated Water Resources Development- A Plan for Action (1999). Report of the National Commission for Integrated Water Resources Development Plan, Ministry of Water Resources, Government of India (GoI), New Delhi, India, Sep.

[4] IWRS (1996). Theme paper on Inter-basin transfers of Water for National Development: Problems and Perspectives, Indian Water Resources Society, Indian Institute of Technology (IIT) Roorkee, Uttarakhand, India.

[5] Rao V. L. N., Desai V. R. and Kumar N. (2007). Inter-basin Water Transfer Proposal for Flood Moderation, $12^{\text {th }}$ National Water Convention, National Water Development Agency (NWDA) and Government of Puducherry, Puducherry, India, November, 218-238.

[6] Bhaduri A. and Barbier E. B. (2011). Water allocation between states in inter-basin transfer in India, Intl. J. River Basin Management, 9 (2), 117-127.

[7] Bonkile S. D. and Pajgade P. S. (2012). Art of intra and Interbasin water transfer, J. of Engg. Research and Studies, 3 (3), 22-27.

[8] George M., Korgaonkar P. D. and Geetha K. (2014). Interlinking of river basins -a review, Intl. J. of Civil, Structural, Environmental and Infra. Engg. Research and Development, 4 (2), 33-44.
[9] Gupta J. and Van der Zaag P. (2008). Inter-basin water transfers and integrated water resources management: Where engineering, science and politics interlock, $J$. of Physics and Chemistry of the Earth, 33, 28-40.

[10] Hamaideh A., Hoetzl H. and Raggad M. A. (2017). Water harvesting: Groundwater storage reservoir in Wadi Ishe, Jordan. Scientific Research and Essays, 12 (2), 9-23.

[11] Mahabaleshwara H. and Nagabhushana H. M. (2014). Interbasin water transfers in India - a solution to hydrological extremities, Intl. $J$. of Research in Engineering and Technology, 3 (3), ISSN: 2321-7308.

[12] Pelkey N. (2003). Linking Rivers, The Hindu Survey of the Environment, Chennai, India.

[13] National Water Development Agency [NWDA] (2003). Interbasin transfer proposals, New Delhi, India.

[14] Verdhen A. (2016). Intra and Inter-basin Linking of Rivers in Water Resources Management, J. of Scientific and Industrial Research, 75, 150-155.

[15] Vyas S. K., Sharma G, Mathur Y. P. and Chandwani V. (2016). Interlinking feasibility of five river basins of Rajasthan in India, Engineering and Material Sciences, 8, 83-86.

[16] http://www.cwc.nic.in/welcome.htm.

[17] http://www.indiawris.nrsc.gov.in/HydroObservationStationAp p.html.

[18] https://www.nrcs.usda.gov/wps/portal/nrcs/detail/soils/survey/ office/ssr10/tr/?cid=nrcs144p2_074846.

[19] Manual on Artificial recharge of ground water (2007). Central Ground Water Board, Ministry of Water Resources, Govt. of India, Faridabad, Haryana, India.

[20] Todd D. K. and Mays L. W. (2011), Ground Water Hydrology, $3^{\text {rd }}$ Ed., Wiley India, New Delhi, India.

[21] IS: 4880 (1976). Code of practice for design of tunnels conveying water, Part III: Hydraulic Design, Bureau of Indian Standards (BIS), New Delhi, India. 